\title{
ResearchOnline@JCU
}

This is the author-created version of the following work:

Harland, Fiona, Stewart, Glenn, and Bruce, Christine (2018) Aligning library and university strategic directions: a constructivist grounded theory study of academic library leadership in Australia and the USA. New Review of Academic Librarianship, 24 (3-4) pp. 263-285.

Access to this file is available from: https://researchonline.jcu.edu.au/54857/

(C) Fiona Harland, Glenn Stewart and Christine Bruce

Please refer to the original source for the final version of this work: 


\title{
Aligning Library and University Strategic Directions: A Constructivist Grounded Theory Study of Academic Library Leadership in Australia and the U.S.A.
}

\author{
Fiona Harland, Glenn Stewart \& Christine Bruce
}

To cite this article: Fiona Harland, Glenn Stewart \& Christine Bruce (2018): Aligning Library and University Strategic Directions: A Constructivist Grounded Theory Study of Academic Library Leadership in Australia and the U.S.A., New Review of Academic Librarianship, DOI: 10.1080/13614533.2018.1498797

To link to this article: https://doi.org/10.1080/13614533.2018.1498797

Accepted author version posted online: 17

Jul 2018.

Submit your article to this journal $\pi$

Џ Article views: 9

View Crossmark data \lceil 


\section{Aligning Library and University Strategic Directions: A Constructivist Grounded Theory Study of Academic Library Leadership in Australia and the U.S.A.}

Fiona Harland ${ }^{\mathrm{a} *}$, Glenn Stewart ${ }^{\mathrm{b}}$, and Christine Bruce ${ }^{\mathrm{c}}$

${ }^{a}$ Faculty of Business, School of Management, Queensland University of Technology (QUT), Brisbane, Australia; ${ }^{b}$ Science and Engineering Faculty, School of Information Systems, Queensland University of Technology (QUT), Brisbane, Australia; ${ }^{c}$ Graduate Research School, James Cook University, Townsville, Australia

Fiona Harland, Corresponding author

Queensland University of Technology (QUT), Faculty of Business, School of Management

2 George Street

Brisbane, Qld 4000

Australia

E-mail address: f.harland@connect.qut.edu.au 


\section{Abstract}

This paper presents a substantive grounded theory that shows how senior library leaders can achieve the library's strategic alignment with the university. The theory suggests that increasing uncertainty causes the library's leadership to consider how the library's strategic contributions can support the university's core priorities while also promoting the library's value and impact. The library's senior leaders must be creative thinkers who are also focused upon their stakeholders. Value-adding strategies include refreshing core library functions and supporting university strategies such as engagement, teaching and learning, and research. The library's strategic planning involves basing the library strategic plan on the university plan, allowing time for it to be implemented, and informing the university of the library's progress. This research is the first to explore the processes senior library leaders can undertake to strategically align the library with the university, while also demonstrating its value and impact to university executive administrators.

Keywords: academic libraries; constructivist grounded theory; Library Directors; strategic planning; vision.

\section{Introduction}

In recent years academic libraries have realised the need to change their relationship with their stakeholders in accordance with the larger goals of the university (Franklin, 2009; Johnson, Adams Becker, Estrada, \& Freeman, 2015, p. 10; McNicol, 2005; O'Sullivan \& Partridge, 2016; Saunders, 2016). This has become increasingly necessary because the recent alarming research of Wolff-Eisenberg (2017) indicates that senior library leaders in the United States "feel increasingly less valued by, involved with, and aligned strategically with their supervisors and other senior academic leadership" (p.4). Some US studies provide evidence that many academic libraries are failing to directly align the library's strategic vision with that of the university (Saunders, 2015, 2016). 
The academic library's strategic alignment with its parent institution is necessary because the success of an organisation's activities relies upon "alignment of the activity to the organisation's strategic, operational or tactical objectives (delivery of value)" (Bourne, 2009, p. 15). To achieve strategic alignment, the library leadership must constantly monitor the university's vision, strategy and goals. This is critical because the library needs to demonstrate that it is contributing to university's goals (Albert, 2014; Jubb, Rowlands, \& Nicholas, 2013, p. 140; Oakleaf, 2010). Moreover, university strategy is subject to frequent change because universities must respond to fluctuating political and economic issues, and they must be sensitive to shifting higher education trends, demographic change and accreditation issues (Otero-Boisvert, 2015, p. 264).

The library's senior leadership are responsible for setting and articulating the library's vision and strategic direction (Garrison, Ryan, \& DeLong, 2012, p. 137). The importance of this strategic leadership function is emphasised by many authors (Kotter, 1996; MandevilleGamble, 2015; Marsick \& Watkins, 1999; Nanus, 1992; Pearn, Roderick, \& Mulrooney, 1995; Senge, 1990; Watkins \& Marsick, 1993). Leaders' persistence in developing vision and implementing strategic planning to realise goals is imperative because an organisation can thrive upon a new vision or fail in the face of a disruptive technology or system innovation (Tellis, 2006, p. 37).

There is no existing theory about how the senior strategic leaders of the library align its vision and strategic goals with those of the university. Therefore, this paper explores the research question:

How can the academic library's senior strategic leaders align the library's vision, strategy and goals with those of the University? 
This paper presents one of the important findings of the doctoral dissertation of Fiona Harland (2017), as summarised in a recent paper by Harland, Stewart, and Bruce (2017). The research of Fiona Harland (2017) explored how library directors ensure the relevance of the academic library to stakeholders. This paper develops a substantive grounded theory and provides a conceptual model that explains the strategies and processes undertaken by the library senior strategic leaders to achieve the library's strategic alignment with the university. The purpose of the theory and visual model is to explain the steps that can guide senior library leaders in their strategic planning.

The paper proceeds with a review of recent literature, identifying the research gap to be addressed. Following this, the paper describes the constructivist grounded theory research approach that was used to develop the substantive theory. The research findings are then presented, followed by the discussion of the findings.

\section{Literature Review}

While the leader's articulation and communication of vision (Marsick \& Watkins, 1999, 2003; Senge, 1990; Watkins \& Marsick, 1993), and implementation of that vision (Kotter, 1996), are emphasised in management literature, guidelines for strategic planning and implementation in the public sector, such as universities and their libraries, are less visible. This is because the vision of a public sector organisation is complicated by government policy and legislation, and the need to be sensitive to their stakeholders' needs (Nanus, 1992)

Within the LIS field, recent studies show that strategic alignment with the university means that academic libraries are changing their relationship with their stakeholders (Franklin, 2009; Johnson et al., 2015, p. 10; McNicol, 2005; Saunders, 2016). There are numerous descriptive case studies describing strategic changes in various university libraries 
(Dole, Dabbour, \& Kott, 2017; Franklin, 2009; Jeal, 2014; Nutefall \& Chadwell, 2012; Wynne, Dixon, Donohue, \& Rowlands, 2016). There is also some study of individual alignment goals. For example, Maddox and Zhao (2017) discuss the development of research performance data as part of university library strategy in a case study of Deakin University Library, Australia.

Robertson (2015) examines Canadian university provosts' perceptions of the library's alignment with the university mission. This study finds that Canadian university provosts regard their libraries' expanded roles as having contributed significantly to the university's mission. However Robertson (2015) does not examine those "expanded roles", and the provosts are vague about how the contribution is measured.

Some studies explore the strategic directions of academic libraries from the view-point of the library's senior strategic leadership. The multiple case study research of Casey (2011, p.323) is significant because it discusses the library director's role and finds that each of the libraries studied showed alignment to and support of their universities' strategic vision, however, it does not discuss the processes involved in aligning strategy.

The Ithaka S+R US Library Survey (Wolff-Eisenberg, 2017) also examines the strategic issues that concern library directors, and finds distinct differences according to library type and the number of years of participants' incumbency. While this survey presents valuable data about their strategies, and the sample is large, it does not explain how senior library leaders align their strategic vision with the university.

Significantly, Saunders (2015) and Saunders (2016) content analysis of the strategic plans of 63 libraries that are members of the Association of College and Research Libraries (ACRL) finds that they are failing to explicitly align their strategic plans with those of the parent institution. Therefore, guidance in strategic processes is necessary. 
There is very little literature that examines the processes of strategic planning in academic libraries. Hernon, Dugan, and Matthews (2014) discuss evidence-based planning and decision making as part of the planning process. Zaugg (2015) suggests the need for a library impact map (LIM) to enable strategic planning. Dole (2013, p. 284) uses a literature review to describe the steps in strategic planning as: vision for the future, a framework of core values for achieving the vision, an environmental scan of issues that may affect the achievement of the vision, developing goals and strategies, and implementing the plan.

Franklin (2009, p. 499) describes the University of Connecticut's approach to the university strategy as beginning with a meeting with administrators to understand the university plan, engage staff in environmental scans and analysing data, and directing a strategic planning team to determine goals. Nutefall and Chadwell (2012) describe a similar process in a single case study about the library realignment at Oregon State University.

This substantive grounded theory adds significantly to the case studies of Franklin (2009) and Nutefall and Chadwell (2012) by providing a broader empirical study and an original contribution of an integrated theory about how the university library aligns its strategy with that of the university.

Therefore, this research builds upon the previous research by examining the perceptions and actions of the senior strategic library leadership in aligning the library's strategy with that of the university.

\section{Research Approach and Design}

\section{Constructivist Grounded Theory Research Approach}

This study's research question asks how the academic library's senior strategic leaders can align its vision, strategy and goals with those of the university. A constructivist grounded theory research approach was chosen primarily because its interpretivist world view enables 
an understanding of the senior library leaders' experiences, values and feelings, and the coconstruction and interpretation of their meanings and multiple realities (Cecez-Kecmanovic \& Kennan, 2013; Charmaz, 2008, p. 402; 2009, p. 138; 2014, p. 239). The interpretivist approach allows for interactions between people, cultural context and time, inviting examination of the complex academic environment at a time of intense global competition between universities. The constructivist grounded theory research approach also seeks to answer the how questions, and to explain action (Charmaz, 2008, p. 398; 2014, p. 239; Denzin \& Lincoln, 2011, p. 8).

Finally, the purpose of the research is to develop a substantive theory that is an interpretation or explanation of the limited area of the academic library context (Charmaz, 2014, p. 344) when current theories are either absent or inadequate (Creswell, 2013, p. 48; Glaser \& Strauss, 1967, p. 32). The literature review presented here demonstrates the paucity of literature that explains how senior library leaders can the align the library's strategic direction with the university.

Kathy Charmaz developed constructivist grounded theory in the 1990's as an interpretivist revision of the original classic grounded theory of Glaser and Strauss (Charmaz, 2009, p. 129; Glaser \& Strauss, 1967). Grounded theory, as devised by Glaser and Strauss (1967) is a systematic way of collecting and analysing data in order to build a theory that is grounded in the data (Charmaz, 2014, p. 1). Constructivist grounded theory uses an inductive form of logic where data collection begins without a hypothesis, and an in-depth literature review is not begun until the theoretical concepts begin to emerge (Charmaz, 2014, p. 7). The reason for these practices is to avoid "forcing the data" or attempting to fit data into a preconceived theory (Charmaz, 2006, p. 5; Glaser, 1978, p. 36; Glaser \& Strauss, 1967, pp. 33-34). 
Constructivist grounded theory method has no defined steps such as data collection followed by analysis. Rather, the constant comparison method of data analysis requires the researcher to constantly compare phrases, ideas or incidents within data transcripts and also to find associations with similar data in other data transcripts (Charmaz, 2014, p. 132; Glaser \& Strauss, 1967, p. 106). The researcher's insights are then woven into a rich theory that includes conceptual categories, processes and relationships that are developed through a memo writing process (Birks \& Mills, 2011, p. 10; 2015, p. 11; Charmaz, 2006, p. 5; Creswell, 2013, p. 85).

\section{Research Design}

This study's overall research sample was purposive, providing data that was relevant to the research question and could produce the richest data (Glaser, 1978, p. 48; Glaser \& Strauss, 1967, p. 36; Morse, 2007, p. 231). The overall sample included 12 experienced library directors from a range of publicly funded university types in Australia and from state system universities in the United States. While this is a small sample for a qualitative study, the constructivist grounded theory method determines that data collection should cease when the data is determined to be sufficient to generate a credible theory (Bowen, 2008; Mason, 2010).

The sample included participants from state system universities in the United States because their public funding system bears similarities to that of Australia (Marginson, 2002a, 2002b; Marginson \& van der Wende, 2009), and American universities have a heavy influence upon the globalised and competitive higher education market (Marginson, 2006, p. 2; Marginson \& van der Wende, 2009, p. 22).

Data collection consisted of intensive semi-structured interviews that helped "develop understanding of the ways in which managers make sense of, and create meanings about, their jobs and their environment" (Qu \& Dumay, 2011, p. 247). After obtaining ethical 
clearance, recruiting of a convenience sample began (Library Directors 1 and 2), and Library Directors 3 to 10 were recruited through snowball sampling, or the suggestions of participants during interviews (O'Reilly, 2009; Patton, 2002). The participants were recruited directly by email. The interviews took place in initial and theoretical sampling phases, from December 2014 to November 2015.

The initial sample of 10 library directors included two participants from each of the following university types: elite Australian universities, Australian technology universities, Australian research-intensive universities, Australian regional universities, and US state system universities, as illustrated in Table 1. The range of specific university contexts provided an opportunity for comparisons and was designed to augment the credibility of the research and the substantive theory (Charmaz, 2014, p. 337). However, we had difficulty in gaining a second participant in the Australian regional uniyersity sector. Library Director 10 was originally interviewed as a participant from the regional university sector, but the university was later identified as more closely aligned with the research-intensive university sector. To compensate for this, we interviewed another regional participant (Library Director 12) during the theoretical sampling phase (see Table 1).

Table 1. Initial and Theoretical Sampling

Participants were sent the initial interview protocol (Appendix) a few days prior to the interview and were then interviewed face-to-face or by Skype ${ }^{\mathrm{TM}}$. The protocol included as few broad, open-ended questions as possible, allowing the interviewer to explore areas for further investigation through active listening techniques (Charmaz, 2014, p. 65). The interview questions reflected Glaser's (1992, p. 22) concept of abstract wonderment. They were stripped of any theoretical concepts that may have discouraged the data from emerging from participants. The interview protocol consisted of a broad main question, followed by 
more focused related questions, which were asked if the response to the main question was too short, or if participants preferred to answer them.

Following each recorded initial sampling interview, whose median length was 41 minutes, the lead researcher transcribed and coded the data aided by NVivo10 ${ }^{\mathrm{TM}}$ qualitative analysis software. The comparison of data within transcripts and with other transcripts enabled new leads to be followed up in subsequent interviews (Charmaz, 2014). When the initial interviews were completed, the initial codes were categorised into focused codes, which represented the most frequent or significant codes (Charmaz, 2014, p. 140).

Analysis of the focused codes and their sub-categories revealed gaps in the data in the participants' decision-making processes. Another area for further exploration was the different perspectives of the elite libraries and the regional libraries in several areas (Harland, 2017). The theoretical sampling stage followed with two new open-ended interview questions (Appendix). To explore decision-making processes, library directors who had engaged in major library restructuring were sought (Library Directors 7, 11 and 12)). New participants from one elite and one regional university (Library Directors 11 and 12) were also recruited to ensure credibility of the data from these university types. The same process of data analysis through constant comparison of data led to the conclusion that no new or significant codes had emerged, that the focused codes and their sub-categories were saturated with data, and that the data collection could cease (Charmaz, 2014; Glaser \& Strauss, 1967, p. $61)$.

The theoretical coding stage involved abstracting the focused codes into theoretical categories (Charmaz, 2014). For example, the focused code of "Thinking strategically to enhance the library profile" was defined as "Culture" (Glaser, 1978). This phase also entailed defining the relationships between the focused codes, as illustrated by the arrows in Figure 1 The categories and focused codes, and the relationships between them were 
recorded in memos, which were then sorted and written as theory (Charmaz, 2014). Finally, four of the participants were asked to comment on a draft model of the theory, answering questions in the resonance section of the Appendix. This measured whether the theory resonated with the participants and therefore credibility of the theory.

\section{Findings}

The library directors who participated in this research emphasised that one way to maintain relevance to stakeholders is to align the library's vision, strategy and goals with those of the university. Ten of the 12 research participants mentioned the importance of alignment, and this factor began the discourse in four of the interviews (Library Directors 4, 7, 8, and 9). The participants used the term "alignment" frequently and similar phrases such as "strategic intent", "strategic vision", or "linking strategy", with Library Director 9 stressing that "the university strategic plan is critical regarding relevance".

\section{The Challenge: Increasing Uncertainty about the Future}

The library directors participating in this research nominated increasing uncertainty about the future as a major challenge for their libraries. Uncertainty arises from uncontrollable factors that are external to the university, compelling the university to change its strategies. Uncertainty also derives from changes in the university community that force the library to change its strategies and goals.

Participants stated that the globalisation of higher education meant that universities are competing to achieve higher rankings in global rankings lists such as the Times Higher Education World University Rankings ${ }^{\mathrm{TM}}$. For example, Library Director 5 stated that “ $W$ 're number [x] in the world in Times Higher Ed [sic] and that's where we're really seeing our comparators". Moreover, Library Directors 3, 5, and 6 noted that Massive Open Online 
Courses (MOOCS) allowed students to complete online courses from prestigious universities, adding another challenge for universities.

Changes in government higher education policy often force change upon the library. For example, the possible deregulation of the Australian higher education sector meant greater financial pressure on universities, destabilising the job security that had characterised the academic library sector in Australia. Several library directors referred to budget uncertainties caused by economic fluctuations. Library Director 9 was concerned about the linkage of the university's funding to the price of carbon fuel exports. Library Director 9 stressed that large budget cuts were made following the global financial crisis.

Library directors also stressed the challenge of advances in information and communication technologies. Library Director 1 called this the "dynamically changing information landscape" and other library directors mentioned digital learning technology, ebooks, virtual reality, mobile technologies and game technology. Library Director 6 emphatically stated the challenge caused by user preference for Google ${ }^{\mathrm{TM}}$ as a search tool:

We've invested heavily in these information resources, digital information resources, and, you know, technology has enabled us to deliver much of our collections online, and we make considerable investment in those electronic resources. But Google ${ }^{\mathrm{TM}}$ really still remains the tool of choice for our users and we know that through various surveys and evidence-based practice that's been undertaken.

Within the university itself, participants were concerned about changes in university strategic focus and campus infrastructure, and course changes.

\section{Response: Responding to Changes in University Strategy}

The library director moves to alter library strategy in alignment with changes in university strategic planning and priorities. All library directors in the initial sample remarked 
upon the need for an appropriate response. The participants referred to the university strategic plan as "strategic directions", "strategic plans", or "focus". At times, the library's parent unit or division directed the library (Library Directors 2, 3, and 7).

According to the participants it was important to be acutely aware of the university strategic plan, which presents the mission or vision of the university, its long and short-term goals, and the strategies to achieve those goals. Some library directors (8 and 10) referred to being directed by the university or the Vice-Chancellor to address priorities and Library Director 10 stated that the library was sometimes set targets or goals to meet.

The university restructure was observed to be another instigator of change and was often preceded by changes to university strategy or by budget cuts to the university caused by outside economic factors. Library Director 9 noted that funding cuts made fewer staff work harder to achieve the same outcomes. Some participants said it was easy to feel overwhelmed by such change, but Library Director 8 forecast a dire consequence of non-response:

... and if we don't respond we're seen as an out rider. You know, an independent sort of organisation that just goes its own road and you become irrelevant, and they do something about you.

The senior strategic library management team collectively scrutinise the university strategic plans and concentrate on the core priority areas of the university that involve the library. Library Director 6 stated "we've got groups of staff at the moment tasked with looking at the core priority areas of the university",

\section{Strategy: Thinking Strategically to Enhance the Library's Profile}

The response to the university's strategic plan requires the library senior management team to consider how the library can contribute to the university's goals while enhancing the library's profile. Library Director 1 proposed a systemic approach that involves seeing how 
the library functions as part of the whole university. Library Directors 9 and 10 noted that they begin this phase by ensuring senior management are focusing upon strategic thinking. This strategic thinking entails embracing strategic priorities as opportunities to enhance the library's profile (Library Directors 1, 2, 7, 9, and 10). Library Director 5 commented that this is necessary "so that we can be seen as relevant for the new business lines that the university's pursuing”. Library Director 6 agreed that "the university library's brief is becoming broader than it has been before. We're being expected to contribute to new areas, which is a great opportunity for libraries"

All participants referred to the importance of identifying the university's strategic goals, and then seeking opportunities that can support the university strategies, while accounting for the constraints on skills and budget. Library Director 7 called this "adding value", and Library Director 6 stated that "this is value to the university's core priorities". The process involved: identifying opportunities that add value to the university; maintaining and refreshing core library functions; supporting university engagement strategy; supporting the university’s teaching and learning strategy; supporting research strategy; and finally reflecting on the impact of the library's initiatives on university strategy.

Some library directors stressed that their role and responsibility involved identifying or assessing new opportunities and directions for the library that would add value or deliver impact to the university (Library Directors $1,7,10$ ). Library Director 7 pointed out that maintaining the library's relevance was about:

Making sure that we look at where we can add value. So, it's about having strategies which align with the university strategies, but also strategies that are going to capitalise on things that are happening in the environment where the library can add value. 
Library Director 1 stated the importance of identifying the purpose of new initiatives:

Since 2008 I have implemented in my workplace a systems design initiative which from the outset, requires that co-participants or colleagues identify the purpose of the system or systems within the larger organisational context.

The library can add value by determining its ability to perform extra functions according to its areas of expertise. Library Directors 2 and 7 identified the library's expertise in the areas of communications, customer support, and information management, providing a central service location for the university, and providing information literacy skills to students and staff. However, participants recognised that the library must still perform its traditional core functions such as curating and enabling discovery and access to both subscription and open access resources. This required a heavy investment in technology. Yet faculties and administration in some universities still require the library to maintain print resources (Library Director 6). Traditional library services also included the provision of silent study space, which Library Director 8 stated was "a constant expressed desire from our students". Less traditional spaces included group spaces, gallery spaces for art exhibitions or research exhibitions, creative spaces, games rooms and media editing and production suites.

The second way participants perceived the library was adding value was by providing support for university engagement strategy (Library Directors 3, 4, 5, 6, 7). Library Director 3 stated that engagement with stakeholders was the library's main strategy for maintaining and extending its relevance, and Library Director 12 was restructuring the library to be focused upon engagement and collaboration. The importance of engagement strategy to Australian universities was borne out in one of the Australian elite university libraries, which fell within the university's organisational area of engagement. Different types of university library had different strategies for supporting the university's engagement strategy. For example, the elite university libraries of Library Directors 5 and 11 employed staff in 
marketing and fundraising, while regional area university libraries focused upon supporting the engagement and retention of first year students (Library Directors 4, 7).

Supporting the university's learning and teaching strategy was also important, and involved librarians' participation in university learning and teaching committees, curriculum transformation committees, providing learning support for STEM programs, building academic skills advisory services, or as Library Director 2 commented:

Things like student success and retention, first year experience, equity, ... the Curriculum Standards Reference Group, which is the overarching committee that reviews all curriculum [sic] in the university. So, for example, I sit on that committee.

Some Library Directors also stated that the library was teaching "new literacies" (Library Directors 7,8), which entailed an amalgam of literacies such as information and computer technology (ICT), information, learning styles and media.

Finally, the participants perceived that their libraries add value by supporting university research strategy. According to Library Director 10, research support was an imperative for libraries and the library's function was "to augment the research endeavour. Not just support it, but through our professional capability, augment it; make it better; make it stronger".

Libraries were augmenting the research conducted at their universities in ways that included strengthening their research support teams (Library Directors 2 and 10). Some universities' open access policies required researchers to deposit their research in the university repository, and the library had an important role in promoting this policy (Library Directors 2, 3, 8, 10).

Scholarly communication support was another library function that helped academics and researchers to publish. University libraries have discovered new business models for publishing and have provided support and advice to researchers about publishing, citation 
impact and bibliometric data. Library Director 10 reported moves to provide mobile impact analysis reports, and Library Director 3 stated:

Some of the restructuring that I've done over the last couple of years have been to highlight what we do for research, and also to develop some new services whereby we do reports for academics about their publications output and how they're tracking.

Most participants reported they were providing research data management support for the university, but Library Directors 7 and 10 explained that their endeavours in this field were in their infancy. Nevertheless, Library Director 2 had secured external funding to advance in this area.

\section{Culture: Thinking Creatively and Being Customer-Focused}

The kind of culture required of the library executive in strategic planning includes creative thinking and a customer-focused service culture. Library Directors 1 and 12 used the creative ideas of students when reimagining or restructuring the library. Library directors had gained creative ideas from students through involvement with student projects, known as "library as lab" (Library Director 1) or through informal or formal data gathering techniques. Library Director 9 praised the creativity of staff in coping with staff redundancies, and Library Director 5 noted the library's creative use of social media to engage with students and Library Director 8 used creativity in establishing a new visual identity for the library:

\footnotetext{
...we've had feedback from a senior academic, saying "Why is the Library the only cool looking place in the whole university. We're a school of $[X X X X]$. We don't look that cool." That's really nice feedback to get. There's that culture - that we understand design.
}

Customer-focused culture is necessary for the library to be engaged in and responsive to the university's strategic goals. The university executive is a major stakeholder for the 
library, and therefore the participants stated that they must be actively engaged, communicating, networking and collaborating with all key executive level stakeholders, as Library Director 5 remarked, “it's about my involvement, my personal connections with those key internal stakeholders in the University."

Such networking with the university executive takes place in both formal and informal ways. Most participants revealed they had little direct access to the university's President or Vice-Chancellor, although Library Director 2 mentioned "strategic walk arounds" with the Vice-Chancellor, and Library Director 1 was meeting with the university's leaders to ask how to communicate about technology, collections, services and technologies. In general, though, the participants communicated directly with heads of faculty and department heads through formal structures such as Academic Board. Informal settings include the Vice-Chancellor's annual retreat (Library Director 5), offering library space for high level and high-profile projects (Library Director 6), or collaborating with the university's research office (Library Director 10).

The library directors also ensured that the library was rapidly responsive to the needs of customers, as Library Director 4 states:

I think for us here, and possibly for everybody, it's being willing to be responsive, but also being really flexible so when you try something and it doesn't go the way you think it's going to go, rather than thinking, "Well that was a failure”, taking a step back and thinking, "What happened there and what can we do", and going back to the stakeholders where we can and trying to work through with them what it is that they need and what we can do. I think we've just got to be very nimble.

Participants were acutely aware of the need to promote a highly visible library because, as Library Director 3 states "you never know who in the community is going to be speaking to 
a Dean, an academic, your Vice Chancellor." Library Director 10 also measured the success of the library because "the Vice-Chancellor mentions our contribution at various fora".

\section{Goal: Planning for an Aligned Library}

An aligned strategic plan is achieved by basing the library strategic document upon the university plan, allowing time for the plan to be completed, and reporting the library's progress to university administrators.

Library planning is based upon the university plan, and Library Director 11 stressed that it "involved stakeholders and we deliberately and logically aligned it with the university's strategic plan to make sure we were aligned." The plan involves developing a vision statement and goals, and then adopting strategies for achieving those goals. Examples of such strategies include succession, workforce and facilities planning. The library directors' strategic focus, as stated above, included refreshing traditional library services, and supporting the university's strategies of supporting research, learning and teaching, and stakeholder engagement. Library strategic planning also includes measurement indicators that set targets and key performance indicators (KPI's) that set a benchmark for measurement. Some participants reported that the library strategic plan is revised annually, while others have annual operational planning.

Several participants stressed the necessity of allowing time for the process to occur, and then reporting on the progress made on those goals and their impact to the university. Participants revealed the difficulties of reporting to university administrators, where statistics do not always portray library usage properly. However, Library Director 9 discussed reporting actioned plans and successes, and remarked upon the importance of the reporting language: 
We need to use terminology so that when we talk about library instruction we really need to talk about student success and retention because those are university priorities and that is the language that the university uses.

\section{The Integrated Theory of Academic Library Strategic Alignment}

The interview data was organised to demonstrate the processes that happen in aligning the library's strategy with that of the university. We determined the phases of the process and their relationships with each other (Charmaz, 2014, p. 245). The process began with participants recognising the challenge they faced in maintaining the relevance of their libraries to stakeholders. The challenge was the increasing uncertainty about the future of the university. Participants then determined that the library needed to respond appropriately to the consequent changes in university strategic planning. Following this, the senior library management team engage in strategic thinking that focuses upon enhancing the library's profile. This involves taking advantage of the opportunities presented by the university's strategic plan. Concurrently, the library leadership team must foster a management culture that encourages creative thinking and a customer-centric focus. The senior library leadership team then devise a strategic plan that aligns with the vision and strategy of the university and creates strategic goals that enhance the library's profile.

The process of aligning the library's strategic vision with that of the university is illustrated in the conceptual model of Figure 1. The single-headed arrows represent a process (Saldaña, 2013, p. 251), while the double-headed arrow signifies an interdependent relationship, where the actions depend upon each other (Glaser, 1978, p. 76).

Figure 1. The Integrated Theory of Academic Library Strategic Alignment 


\section{Discussion}

The first finding that universities are affected by increasing uncertainty reflect other findings that universities and their libraries must respond to constant changes in the general economy, legislation, higher education trends, demographic trends and accreditation issues (Delaney \& Bates, 2015; Gwyer, 2015; Nanus, 1992; Otero-Boisvert, 2015).

The finding that the senior library leadership must respond to changes in the university's strategic plan by creating the library's strategic vision in alignment with that of the university is widely regarded as an important leadership function (Kotter, 1996; Mandeville-Gamble, 2015; Marsick \& Watkins, 1999; Nanus, 1992; Pearn et al., 1995; Senge, 1990; Watkins \& Marsick, 1993). The findings also reveal the importance of recruiting and developing library leaders that are supportive of the vision (Jeal, 2014; Leong \& Anderson, 2012; Mandeville-Gamble, 2015).

The research also finds that the library leadership team must be strategic thinkers who are focused upon enhancing the library's profile. Strategic thinking is "conceptual, systemsoriented, directional, and opportunistic thinking" (Goldman \& Casey, 2010, p. 120), and a visionary leader sees future developments as opportunities for the organisation (Nanus, 1992). While the individual strategies such as research support are covered well in LIS literature (Haddow \& Mamtora, 2017), this study provides an original empirical basis to the views of Schein (2010) and Goldman and Casey (2010), who suggest the employment of staff who are capable of strategic thinking.

This study also finds that the senior library leaders must be creative thinkers who are customer focused. While the necessity of a customer-focus or service culture is wellrecognised in academic libraries (Mestre \& LeCrone, 2015; Michalak, 2012; Stoffle \& Cuillier, 2010), the difficulties of dealing with university administrators is less well 
understood. This study finds that the library directors regard attaining the high regard and support of administrators and good management of these interpersonal relationships as crucial to aligning the library's strategy with that of the university. These findings complement the research of Otero-Boisvert (2015), who finds that persistence in advocacy and good relationship management with administrators over several years helps in the successful procurement of funding.

The role of creative thinking in library strategic planning is less well known, and this is possibly because academic libraries tend to borrow ideas from other libraries (Jantz, 2012a, 2012b). Creativity is "the production of original, high quality, and elegant problem solutions" (Mumford, Hester, \& Robledo, 2012, p. 4), and is important because organisations that can adapt to constant change will have leaders who are innovative and creative thinkers (Maloney, Antelman, Arlitsch, \& Butler, 2010, p. 337). Therefore, the leader's role in nurturing and guiding creative thinking is emphasised by Perkins, Lean, and Newbery (2017), who state that visions are enacted, and strategic planning is preceded by a guided ideation process. Moreover, to ensure creative innovation is occurring in the library, the senior strategic leadership must invest sufficient time and resources (Jantz, 2016; Wokurka, Banschbach, Houlder, \& Jolly, 2017).

Finally, the library's senior leadership must incorporate the university's vision and strategic goals into library planning, supervise their implementation over time, and report back to the university on its progress. The library's organisational vision will include a clearly articulated guiding philosophy that includes core values and beliefs and a statement of purpose (Collins \& Porras, 2008; Kets De Vries \& Florent-Treacy, 2002). The vision is then enacted through planning, which involves an ideation process guided by the senior leader (Perkins et al., 2017). This process entails the development of strategic long-term goals, with planned actions that are designed to achieve those goals (Perkins et al., 2017). The long-term 
goals provide a measurable reference point for their achievement (Grant, Butler, Orr, \& Murray, 2014). The library's strategic planning process involves systematic procedures that include strategic business modelling, performance audits and gap analysis and closure, the development of action plans, and contingency planning (Nolan, Goodstein, \& Goodstein, 2008).

The persistence of the senior leadership team in implementing a strategic plan over the long-term is imperative. This key factor is demonstrated in the ethnographic research of Otero-Boisvert (2015), who finds that successful library leaders "built on years of maintaining excellent relationships with key administrators and colleagues, building a history of credibility as good fiscal managers, demonstrating a commitment to the university's overall mission and engaging in reciprocal acts as needed" (p.269). Moreover, reporting back to the university administration in a way that is meaningful to them and demonstrates the library's impact on university outcomes is important to obtain extra resources or to form collaborative partnerships (Albert, 2014; Delaney \& Bates, 2015; Hernon et al., 2014).

Therefore, the findings of this research differ from the extant literature about library strategic planning (Dole, 2013; Hernon et al., 2014) in its emphasis on the role of strategic thinking and creativity in strategic planning processes.

\section{Limitations and Future Directions}

A limitation of this research is the small size of the sample. However, the constructivist grounded theory method determines sample size by the depth of data saturation, whether the theory makes sense, and checking that it resonates with the participants (Bowen, 2008, p. 140; Charmaz, 2014; Mason, 2010). The theoretical model was discussed with four participants during a final phase of interviews, and all agreed that it reflected their experience (Harland, 2017). The exploratory nature of this research also means that future research is 
required to test the theory. The small size of the sample also means future research could focus upon the variations in strategic focus between regional and metropolitan universities, or upon academic libraries in various countries. Further research can also explore how creative and strategic thinking can be nurtured in academic libraries.

\section{Practical Implications of the Theory}

The findings in this paper will benefit senior strategic library leaders in creating an academic library that is relevant to the university's wide range of stakeholders. In particular, the findings demonstrate how senior library leaders can ensure that the library is acknowledged by university senior administrators as a major contributor to the university's vision and strategic goals.

The theory emphasises the necessity of frequent library strategic planning processes, and therefore, role descriptions will prioritise strategic planning for senior strategic leaders and may increase the frequency of strategic planning processes. The theory also highlights the capabilities and attributes required of the senior leadership of the library. This means that the selection criteria for library executive staff will accentuate the necessity of familiarity with the university's strategic directions and with strategic planning processes, and to be sensitive and responsive to any changes in the university's direction. The library's senior strategic leadership will also require the ability to be analytical and strategic thinkers who are able to sense opportunities that may enhance the profile of the library. They should also have personal attributes that include creativity and customer-focus. Finally, the library's senior strategic leaders should have an open outlook that enables them to work collegially with the university's senior academic and administrative staff. 


\section{Conclusion}

This paper addresses the problem academic libraries' face in aligning their vision, strategy and goals with those of the university. The theory developed from this research suggests that the senior strategic library leaders must respond to the continuous changes in the higher education environment and to the subsequent changes in the university's strategic plans. This requires the senior library leadership to be strategic thinkers, who focus upon strategies that will enhance the reputation of the library with the university administration and other stakeholders. They will also be creative and customer-focused. The theory then suggests that the library's senior leadership must commit time and energy on a cycle of planning that is based upon the university's strategic plans and any changes to its vision, strategy and goals. This research provides a unique contribution to the literature on academic library strategic planning through its emphasis on the necessity for the senior leadership team to have the capabilities for creativity and strategic thinking.

Acknowledgments

The first author was a recipient of an Australian Postgraduate Award Scholarship during this research.

Ethics clearance was gained from the QUT Ethics Committee for the conduct of this research (QUT Ethics Approval Number 1400000814). 


\section{Appendix}

\section{Main interview question}

1) How do you maintain the relevance of your library to your stakeholders and extended community at the present time?

\section{Related interview questions}

2) Who are the stakeholders in your library at the present time?

3) What do you perceive to be the challenges facing your library at the present time?

4) How do you discover the challenges that affect your library?

5) How do you deal with these challenges?

6) How do you know that you and your staff are dealing with these challenges adequately?

7) Can you think of anything else which helps the library to achieve relevance to its stakeholders?

\section{Theoretical sampling questions}

1) How did you make the decisions about your library restructure?

2) Are there any factors that indicate success in maintaining the library's relevance to the university?

\section{Resonance questions}

1) What resonated with you in this model?

2) What is still important in 2016 ?

3) What is of lesser importance in 2016 ?

4) What is missing in the model in your current context?

5) What is in the foreground?

6) What is in the background? 
Albert, A. B. (2014). Communicating library value - the missing piece of the assessment puzzle. Journal of Academic Librarianship, 40(6), 634-637. doi:10.1016/j.acalib.2014.10.001

Birks, M., \& Mills, J. (2011). Grounded theory: A practical guide. Los Angeles: SAGE.

Birks, M., \& Mills, J. (2015). Grounded theory: A practical guide (2nd ed.). Los Angeles: SAGE.

Bourne, L. (2009). Stakeholder relationship management : A maturity model for organisational implementation. Abingdon, UK: Routledge.

Bowen, G. A. (2008). Naturalistic inquiry and the saturation concept: A research note. Qualitative Research, 8(1), 137-152. doi:10.1177/1468794107085301

Cecez-Kecmanovic, D., \& Kennan, M. A. (2013). The methodological landscape: Information systems and knowledge management. In K. Williamson \& G. Johanson (Eds.), Research methods: Information, systems and contexts (pp. 113-137). Prahran, Vic.: Tilde.

Charmaz, K. (2006). Constructing grounded theory: A practical guide through qualitative analysis. London: SAGE.

Charmaz, K. (2008). Constructionism and the grounded theory method. In J. A. Holstein \& J. F. Gubrium (Eds.), Handbook of constructionist research (pp. 397-412). New York: Guilford Press.

Charmaz, K. (2009). Shifting the grounds: Constructivist grounded theory methods. In J. M. Morse, P. N. Stern, J. Corbin, B. Bowers, K. Charmaz, \& A. E. Clarke (Eds.), Developing grounded theory: The second generation (pp. 127-154). Walnut Creek, CA: Left Coast Press.

Charmaz, K. (2014). Constructing grounded theory (2nd ed.). Los Angeles: SAGE.

Collins, J. C., \& Porras, J. I. (2008). Organizational vision and visionary organizations. California management review, 50(2), 117-137. doi:10.2307/41166438

Creswell, J. W. (2013). Qualitative inquiry and research design: Choosing among five approaches. Thousand Oaks, CA: SAGE.

Delaney, G., \& Bates, J. (2015). Envisioning the academic library: A reflection on roles, relevancy and relationships. New Review of Academic Librarianship, 21(1), 30-51. doi:10.1080/13614533.2014.911194

Denzin, N. K., \& Lincoln, Y. S. (2011). The discipline and practice of qualitative research. In N. K. Denzin \& Y. S. Lincoln (Eds.), The SAGE handbook of qualitative research (4th ed., pp. 1-19). Los Angeles: SAGE.

Dole, W. V. (2013). Strategic planning and assessment: Pigs of the same sow? Journal of Library Administration, 53(4), 283-292. doi:10.1080/01930826.2013.865397

Dole, W. V., Dabbour, K., \& Kott, K. (2017). Dialogic approaches to strategic planning in academic libraries: An appreciative inquiry case study at Oviatt Library. Journal of Library Administration, 57(4), 468-480. doi:10.1080/01930826.2017.1300499

Franklin, B. (2009). Aligning library strategy and structure with the campus academic plan: A case study. Journal of Library Administration, 49(5), 495-505. doi:10.1080/01930820903090862

Garrison, J., Ryan, M., \& DeLong, K. (2012). Moving up: Positioning for director roles in academic libraries. In B. L. Eden (Ed.), The associate university librarian handbook : A resource guide (pp. 137-159). Lanham, MD: Scarecrow Press.

Glaser, B. G. (1978). Theoretical sensitivity. Mill Valley, CA: The Sociology Press.

Glaser, B. G. (1992). Basics of grounded theory analysis. Mill Valley, CA: Sociology Press. 
Glaser, B. G., \& Strauss, A. G. (1967). Discovery of grounded theory : Strategies for qualitative research. New York: Aldine

Goldman, E. F., \& Casey, A. (2010). Building a culture that encourages strategic thinking. Journal of Leadership \& Organizational Studies, 17(2), 119-128. doi:10.1177/1548051810369677

Grant, R., Butler, B., Orr, S., \& Murray, P. A. (2014). Contemporary strategic management: An Australasian perspective: John Wiley \& Sons Australia, Ltd.

Gwyer, R. (2015). Identifying and exploring future trends impacting on academic libraries: A mixed methodology using journal content analysis, focus groups, and trend reports. New Review of Academic Librarianship, 21(3), 269-285. doi:10.1080/13614533.2015.1026452

Haddow, G., \& Mamtora, J. (2017). Research support in Australian academic libraries: Services, resources, and relationships. New Review of Academic Librarianship, 23(23), 89-109. doi:10.1080/13614533.2017.1318765

Harland, F. (2017). How the University Librarian ensures the relevance of the library to stakeholders: A constructivist grounded theory. (Doctoral dissertation). Retrieved from https://eprints.qut.edu.au/106745/

Harland, F., Stewart, G., \& Bruce, C. (2017). Ensuring the academic library's relevance to stakeholders: The role of the Library Director. The Journal of Academic Librarianship, 43(5), 397-408. doi:10.1016/j.acalib.2017.06.009

Hernon, P., Dugan, R. E., \& Matthews, J. R. (2014). Getting started with evaluation. Chicago: American Library Association.

Jantz, R. C. (2012a). A framework for studying organizational innovation in research libraries. College \& Research Libraries, 73(6), 525-541.

Jantz, R. C. (2012b). Innovation in academic libraries: An analysis of university librarians' perspectives. Library \& Information Science Research, 34(1), 3-12. doi:10.1016/j.lisr.2011.07.008

Jantz, R. C. (2016). Managing creativity: The innovative research library. Chicago, IL: Association of College and Research Libraries.

Jeal, Y. (2014). Strategic alignment at the University of Manchester library: Ambitions, transitions, and new values. New Review of Academic Librarianship, 20(3), 278-295. doi:10.1080/13614533.2014.919328

Johnson, L., Adams Becker, S., Estrada, V., \& Freeman, A. (2015). NMC horizon report: 2015 library edition Retrieved from http://cdn.nmc.org/media/2015-nmc-horizon-reportlibrary-EN.pdf

Jubb, M., Rowlands, I., \& Nicholas, D. (2013). Value of libraries: Relationships between provision, usage, and research outcomes. Evidence Based Library and Information Practice, 8(2), 139-152.

Kets De Vries, M. F. R., \& Florent-Treacy, E. (2002). Global leadership from A to Z: Creating high commitment organizations. Organizational Dynamics, 30(4), 295-309. doi:https://doi.org/10.1016/S0090-2616(02)00067-0

Kotter, J. P. (1996). Leading change. Boston, MA: Harvard Business School Press.

Leong, J., \& Anderson, C. (2012). Fostering innovation through cultural change. Library Management, 33(8/9), 490-497. doi:10.1108/01435121211279858

Maddox, A., \& Zhao, L. (2017). University library strategy development: A conceptual model of researcher performance to inform service delivery. New Review of Academic Librarianship, 23(2-3), 125-135. doi:10.1080/13614533.2017.1342673 
Maloney, K., Antelman, K., Arlitsch, K., \& Butler, J. (2010). Future leaders' views on organizational culture. College \& Research Libraries, 71(4), 322-347. doi:10.5860/crl47

Mandeville-Gamble, S. (2015). Communicating and implementing an organization vision. In F. Wilkinson \& R. Lubas (Eds.), Practical strategies for academic library managers (pp. 1-13). Santa Barbara, CA: ABC-CLIO.

Marginson, S. (2002a). Education in the global market: Lessons from Australia. Academe, $88(3), 22-24$.

Marginson, S. (2002b). Nation-building universities in a global environment: The case of Australia. Higher Education, 43(3), 409-428. doi:10.1023/A:1014691304966

Marginson, S. (2006). Dynamics of national and global competition in higher education. Higher Education, 52(1), 1-39. doi:10.1007/s10734-004-7649-x

Marginson, S., \& van der Wende, M. (2009). The new global landscape of nations and institutions. In OECD (Ed.), Higher education to 2030 (Vol. 2, pp. 17-62). Paris: OECD Publishing.

Marsick, V. J., \& Watkins, K. E. (1999). Facilitating learning organizations: Making learning count. Aldershot, UK: Gower.

Marsick, V. J., \& Watkins, K. E. (2003). Demonstrating the value of an organization's learning culture: The Dimensions of the Learning Organization Questionnaire. Advances in Developing Human Resources, 5(2), 132-151. doi:10.1177/1523422303005002002

Mason, M. (2010). Sample size and saturation in PhD studies using qualitative interviews. Forum : Qualitative Social Research, 11(3). Retrieved from http://www.qualitativeresearch.net/index.php/fqs/article/view/1428/3028

McNicol, S. (2005). The challenges of strategic planning in academic libraries. New Library World, 106(11/12), 496-509.

Mestre, L. S., \& LeCrone, J. M. (2015). Elevating the student assistant: An integrated development program for student library assistants. College \& Undergraduate Libraries, 22(1), 1-20. doi:10.1080/10691316.2015.1001240

Michalak, S. C. (2012). This changes everything: Transforming the academic library. Journal of Library Administration, 52(5),411-423. doi:10.1080/01930826.2012.700801

Morse, J. M. (2007). Sampling in grounded theory. In A. Bryant \& K. Charmaz (Eds.), The SAGE handbook of grounded theory (pp. 229-244). Los Angeles, CA: SAGE.

Mumford, M. D., Hester, K. S., \& Robledo, I. C. (2012). Creativity in organizations: Importance and approaches. In M. D. Mumford (Ed.), Handbook of organizational creativity (pp. 3-16). London: Academic Press.

Nanus, B. (1992). Visionary leadership: Creating a compelling sense of direction for your organization. San Francisco: Jossey-Bass.

Nolan, T. M., Goodstein, L. D., \& Goodstein, J. (2008). Applied strategic planning: An introduction (2nd ed.). San Francisco, CA: Pfeiffer.

Nutefall, J. E., \& Chadwell, F. A. (2012). Preparing for the 21st century academic library realignment. New Library World, 113(3/4), 162-173.

doi:10.1108/03074801211218543

O'Reilly, K. (2009). Key concepts in ethnography London: SAGE.

O'Sullivan, C., \& Partridge, H. (2016). Organizational change and renewal: Can strategic communication methods ease the pain? A case study from the University of Southern Queensland. New Review of Academic Librarianship, 22(2-3), 282-293. doi:10.1080/13614533.2016.1195418 
Oakleaf, M. (2010). Value of academic libraries: A comprehensive research review and report Retrieved from http://www.ala.org/acrl/sites/ala.org.acrl/files/content/issues/value/val_report.pdf

Otero-Boisvert, M. (2015). Funding the academic library: An ethnographic study. (Doctoral dissertation). Retrieved from http://eprints.qut.edu.au/84749/

Patton, M. Q. (2002). Qualitative research and evaluation methods (3rd ed.). Thousand Oaks, CA: SAGE

Pearn, M. A., Roderick, C., \& Mulrooney, C. (1995). Learning organizations in practice. New York: McGraw-Hill.

Perkins, G., Lean, J., \& Newbery, R. (2017). The role of organizational vision in guiding idea generation within SME contexts. Creativity and Innovation Management, 26(1), 7590. doi:10.1111/caim.12206

Qu, S. Q., \& Dumay, J. (2011). The qualitative research interview. Qualitative Research in Accounting \& Management, 8(3), 238-264. doi:10.1108/11766091111162070

Robertson, M. (2015). Perceptions of Canadian provosts on the institutional role of academic libraries. College \& Research Libraries, 76(4), 490-511. doi:10.5860/crl.76.4.490

Saldaña, J. (2013). The coding manual for qualitative researchers (2nd ed.). London: SAGE.

Saunders, L. (2015). Academic libraries' strategic plans: Top trends and under-recognized areas. The Journal of Academic Librarianship, 41(3), 285-291. doi:10.1016/j.acalib.2015.03.011

Saunders, L. (2016). Room for improvement: Priorities in academic libraries' strategic plans. Journal of Library Administration, 56(1), 1-16. doi:10.1080/01930826.2015.1105029

Schein, E. H. (2010). Organizational culture and leadership (4th ed.). Hoboken, NJ: JosseyBass.

Senge, P. M. (1990). The fifth discipline: The art and practice of the learning organization. New York: Doubleday.

Stoffle, C. J., \& Cuillier, C. (2010). From surviving to thriving. Journal of Library Administration, 51(1), 130-155. doi:10.1080/01930826.2011.531645

Tellis, G. J. (2006). Disruptive technology or visionary leadership? Journal of Product Innovation Management, 23(1), 34-38. doi:10.1111/j.1540-5885.2005.00179.x

Watkins, K. E., \& Marsick, V. J. (1993). Sculpting the learning organization: Lessons in the art and science of systemic change. San Francisco: Jossey-Bass.

Wokurka, G., Banschbach, Y., Houlder, D., \& Jolly, R. (2017). Digital culture: Why strategy and culture should eat breakfast together. In G. Oswald \& M. Kleinemeier (Eds.), Shaping the digital enterprise: Trends and use cases in digital innovation and transformation (pp. 109-120). Switzerland: Springer International Publishing.

Wolff-Eisenberg, C. (2017). Ithaka S+R US library survey 2016. Retrieved from https://doi.org/10.18665/sr.303066

Wynne, B., Dixon, S., Donohue, N., \& Rowlands, I. (2016). Changing the library brand: A case study. New Review of Academic Librarianship, 1-13. doi:10.1080/13614533.2016.1156000

Zaugg, H. (2015). Using a library impact map to assist strategic planning in academic libraries. Library Leadership \& Management, 29(3), 1-17. Retrieved from https://journals.tdl.org/IIm/index.php/IIm/article/view/7102 
Figure 1. The Integrated Theory of Academic Library Strategic Alignment

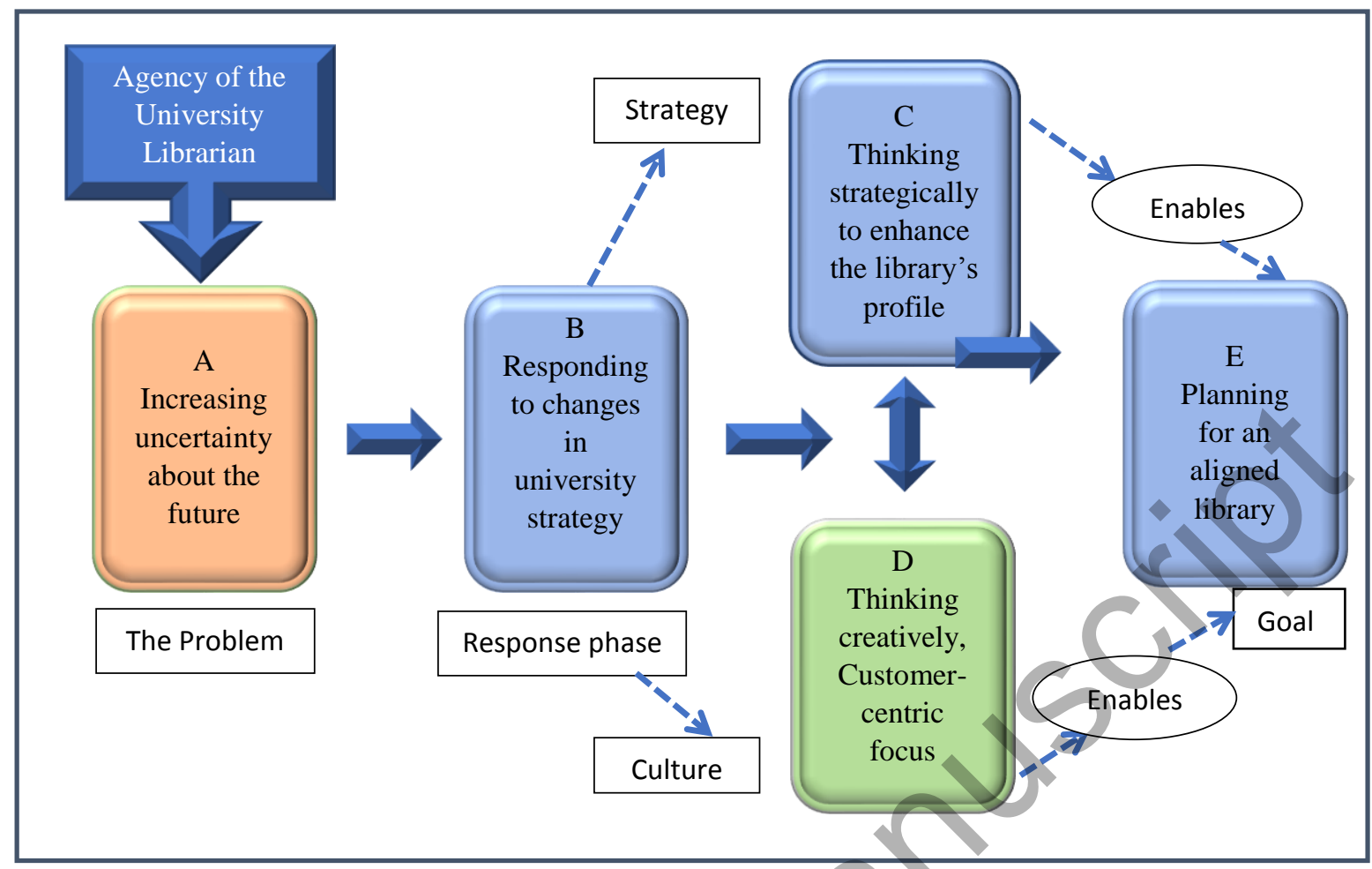

\begin{tabular}{|l|l|l|l|l|l|}
\hline $\begin{array}{c}\text { Sampling } \\
\text { phase }\end{array}$ & \multicolumn{1}{|c|}{$\begin{array}{c}\text { Australian } \\
\text { elite } \\
\text { universities }\end{array}$} & $\begin{array}{c}\text { Australian } \\
\text { technology } \\
\text { universities }\end{array}$ & $\begin{array}{c}\text { Australian } \\
\text { research- } \\
\text { intensive } \\
\text { universities }\end{array}$ & $\begin{array}{c}\text { Australian } \\
\text { regional } \\
\text { universities }\end{array}$ & $\begin{array}{c}\text { United States } \\
\text { state system } \\
\text { universities }\end{array}$ \\
\hline Initial & Director 5 & Director 2 & Director 3 & Director 4 & Director 1 \\
\hline $\begin{array}{l}\text { Initial } \\
\text { (Round 2) }\end{array}$ & Director 6 & Director 8 & $\begin{array}{l}\text { Director 7 } \\
\text { Director 10 }\end{array}$ & Director 9 \\
\hline Theoretical & Director 11 & & Director 7 & Director 12 & \\
\hline
\end{tabular}

Table 1. Initial and Theoretical Sampling 